\title{
The Impact Of HIV/AIDS On International Human Resource Management
}

\author{
Susan Baxter, (E-mail: baxters@cookman.edu), Bethune-Cookman College
}

\begin{abstract}
Economies of global scope afford businesses a competitive advantage. One way to utilize this advantage is to coordinate the leveraging of resources - especially labor. Businesses have attempted to minimize labor costs and risks in an effort to maintain or increase competitive advantage. There is a risk to the global workforce: HIV/AIDS. This disease is striking at the heart of low cost labor pools. The impact on business is being felt now and will be felt for years to come. How large the impact is depends on the level of involvement of multinational businesses in the fight against HIV/AIDS. Multinational businesses must develop policies and procedures to combat this illness, as it is devastating labor pools in various parts of the world.
\end{abstract}

\section{INTRODUCTION}

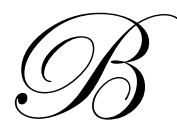

usiness, domestic or international, looks for ways to have a competitive edge to remain successful, increase market share, and effectively achieve corporate goals. Businesses achieve a competitive edge through a coordinated leveraging of resources, reducing costs and risks (Govindarajan \& Gupta, 2001). This focus on economies of global scope ties in with tapping into optimal locations, i.e. having businesses located where there is an availability of needed talent. This facet of business strategy has led many businesses to examine alternative labor sources, furthering the exodus of businesses from primarily domestic markets into a global, or multinational, marketplace. The search for an increased labor supply at lower costs has lead many multinational corporations (MNCs) to locate facilities and/or enter into partnerships in Africa, India, Indonesia and China.

\section{COMPETITIVE ADVANTAGE AND LABOR}

While having a lower cost labor supply does provide a competitive advantage to an organization, have the organizations realized this advantage? Or have there been unexpected expenses that have decreased the advantage of this newly utilized resource? Initially businesses realized significant cost savings with lower cost labor in third world countries. However, one unexpected expense has materialized in the pandemic of HIV/AIDS. "HIV/AIDS is becoming the worst infectious disease catastrophe in recorded history" (Rosen, Simon, Vincent, MacLeod, Fox and Thea, 2003, p. 81). Any MNC with business ventures in a developing country anywhere in the world has been or will be impacted by HIV/AIDS (Rosen, et al; Bloom \& Mahal, 2001). Does HIV/AIDS really impact businesses? If so, how does it impact business? And is the impact enough to cause businesses to become involved in health care, health education and disease prevention? These are very difficult questions to answer, as there have been few empirical studies on the economic impact of HIV/AIDS on business (Bloom \& Mahal, 2001). Those studies that have been completed differ in their approach to outlining costs (Negin, 2005). Most of the current information about the spread of HIV/AIDS and the potential impact on business and economics can be found on government or health care sites (United Nations and World Health Organization) and the popular press (BBC, Fortune, Business Week).

HIV (human immunodeficiency virus), the virus that causes AIDS, has infected more than 35 million people worldwide (Rosen, et al, 2003; Bloom \& Mahal, 2001; UNAIDS, 2004). "At the end of the 1980s the question of the economic impact brought about by a high morbidity and mortality of the human capital was raised with regard to countries where the prevalence of HIV was worrying, in particular those of the African continent" (Aventin \& Huard, 2000). In 2003, five million people were infected with HIV (Gunther, 2004). The concern now is that while 60-70\% of the current population of AIDS infected people live in sub-Saharan Africa, the disease is spreading rapidly in other 
parts of the world (Rosen, et al, 2003; Bloom \& Mahal, 2001; UNAIDS, 2004). AIDS threatens India, Russia, Ukraine and China - nations too big for business to ignore as they are home to about $40 \%$ of the world's population (Gunther, 2004). The United Nations is concerned that up to 10 million Chinese people may be infected by 2010 (HIV rates, 2005). "The World Health Organization projects that for every 20 percent of adults infected in African countries, Africa will experience a one percent decrease in gross domestic product" (Coca-Cola, 2004, p. 2). If AIDS does to these countries what it has done to Africa, the economic consequences would be severe and far-reaching.

Multinational corporations must pay attention to the crisis, examine best practices currently in place, and adapt these to their situation to maintain not only a competitive advantage, but also a viable workforce. Examining the economic impact of a pandemic such as HIV/AIDS utilizing economic theory is difficult due to the limited empirical studies on macroeconomic implications. However, some researchers have noted that economic theory predicts that HIV/AIDS reduces labor supply and productivity, reduces exports and increases imports (Dixon, McDonald \& Roberts, 2002). Five main aspects of business are vulnerable to HIV/AIDS: its workforce, its customer base, its cost of capital, its reputation and the business environment in which it operates (Taylor \& DeYoung, 2003).

This paper will focus on the impact of HIV/AIDS on the workforce and the response of multinational corporations. International human resource management (IHRM) focuses not only on cross-cultural management but also on the aspects of human resource management in multinational firms. Human resource management (HRM) examines the following concepts:

(1) Human resource planning

(2) Staffing (including recruitment, selection and placement)

(3) Performance management

(4) Training and development

(5) Compensation and benefits

(6) Industrial relations

To examine these issues in a multinational corporation you also have to consider the host country where the subsidiary is located, the level of government involvement, and other potential sources of labor. This paper will focus primarily on the concerns of the above-mentioned items, excluding item 3 - performance management.

\section{AFRICA AND AIDS}

Africa has been the focus of most literature on HIV/AIDS and business due to the enormous impact the disease has had on the continent. As noted earlier, over $60 \%$ of all HIV infected people live in sub-Saharan Africa (UNAIDS, 2004). UNAIDS (the United Nations agency coordinating efforts to fight HIV/AIDS) predicts that by the year 2020 over 50 million Africans will have died from HIV/AIDS (Coca-Cola, 2004). The World Economic Forum has identified approximately two-thirds of the MNCs operating in Africa expect AIDS to affect their profits over the next 5 years (Arnst \& Einhorn, 2004). Anglo American PLC, a British mining company with extensive operations in Africa, notes that over $24 \%$ of its workforce in South Africa is infected with HIV (Arnst \& Einhorn, 2004). Lonmin, the world's third biggest producer of platinum, recently reported that as many as $25 \%$ of its employees in South Africa were HIV positive (Pela, 2004). Coca-Cola (2004) and it's bottling companies, working in 56 countries and territories across Africa, employees approximately 62,000 employees representing a total community of over 300,000 people (including family members). Coca-Cola estimates that over $8 \%$ of bottler employees are HIV positive (Coca-Cola, 2004). Other surveys have demonstrated that AIDS has reduced the profits of more than $40 \%$ of manufacturers in some provinces of South Africa (Pela, 2004a). Absenteeism, lower productivity, and employee death are contributors to the decline in profits.

Public and private corporations are not the only ones facing this concern. More than $10 \%$ of South Africa's civil servants are HIV positive (Pela, 2004b). The impact of such a high rate of infection has the government concerned about service provision limitations due to absenteeism and death (2004b). This pandemic is seriously affecting education in South Africa as teachers represent over $40 \%$ of public service employees (2004b). Further, 
South Africa has noted a substantial decrease in school enrollment (4.2\% between 1990-1995 to 0.5\% between 19952000) attributed to rising infant mortality mainly due to HIV/AIDS (2004b).

HIV/AIDS reduces the skilled and unskilled labor supply through increased mortality and morbidity. In South Africa, around $60 \%$ of the mining workforce is between $30-44$ years of age; this is predicted to fall to $10 \%$ within 15 years (Dixon, McDonald \& Roberts, 2002). In the healthcare sector $20 \%$ of student nurses are HIV positive (Dixon, McDonald \& Roberts, 2002).

South Africa's battle with HIV/AIDS is an important consideration for MNCs. South Africa is known for having the "continent's largest economy, one of its leading investors, chief sponsor of regional conflict resolution, largest contributor of personnel to peacekeeping operations in Africa and one of the chief sources of donor aid" (Singh, 2004). The United Nations Population Fund (UNPFA, 2004) estimates that the population in South Africa will be declining and that per-capita economic growth will decline because of "increasing dependency ratios, increased burdens on health systems, constrained investment in productivity, and reduced labor forces because of AIDS". South Africa's ability to participate in peace-keeping missions will begin to be limited as $17-22 \%$ of South Africa's defense force is HIV positive, and South Africa refuses to send HIV-positive troops on peace-keeping missions (Singh, 2004). MNCs and world governments should be concerned that with decreased economic growth and limited peacekeeping services, South Africa's ability to broker conflicts and invest in other regions of the continent will be decreased. This downsizing could have direct impact on the stability and growth of other countries/regions on the continent as well as on business development and growth.

Aventin and Huard (2000) examine the impact of HIV/AIDS on three manufacturing firms in Africa. Historically, concerns about HIV positive employees focused on discriminatory practices by the corporation or vendor. Today, the concerns have moved beyond discrimination issues. The authors (Aventin \& Huard, 2000, p. 171) identified the following direct and indirect costs of HIV/AIDS in the organizations:

\begin{tabular}{|ll|}
\hline \multicolumn{1}{|c|}{ Direct } & \multicolumn{1}{c|}{ Indirect } \\
\hline Medical Care & Recruitment/training (high turnover) \\
Disability pension & Prevention \\
Sick leave & Wage bill for medical personnel \\
Funeral costs & Dismissals/severance pay \\
Attendance at funeral & Increase cost of health insurance \\
HIV screening & Overtime \\
Absenteeism & Decrease of work rates \\
Loss of productivity & Decrease of social bonds \\
Job reorganized & Disruption of knowledge transfer \\
\hline
\end{tabular}

HIV/AIDS increases production costs and it constitutes a threat to knowledge transfer due to increased turnover (Aventin \& Huard, 2000).

Negin (2005) examined how AIDS was impacting rural agriculture in Africa. He noted that the disease impacted labor and production thus increasing the chance of greater poverty. The death of a male head of household has a direct relation to the decrease in production of cash crops, placing a strain on household incomes of up to 68\% reduction in crop value (Negin, 2005). According to a survey by the Zimbabwe Farmers Union, agricultural output in HIV positive households decreased by nearly $50 \%$ (Kwaramba, 1997).

Lower productivity reduces exports and increases imports (Dixon, McDonald, \& Roberts, 2002). “AIDS spells disaster for development" (Negin, 2005, p. 277). The impact of HIV/AIDS in Africa can be seen when one sees "mortality rates, orphan numbers, dependency ratios, and other sources of social pressures rise to unprecedented levels" (Negin, 2005, p. 278). 


\section{AIDS ON THE MOVE}

India has more HIV infected people than any nation except South Africa (Gunther, 2004). There is concern in the medical community that with 300 million poor people, social taboos against talking about sex, and a large migrant worker population, the AIDS crisis in India could spread rapidly (Gunther, 2004). "India's socioeconomic status, traditional social norms, cultural myths on sex and sexuality, large-scale migration and a huge population of marginalized people make it extremely vulnerable to the AIDS epidemic" (UNAIDS, 2004). The World Health Organization (WHO) estimates that there are 5.1 million people infected with HIV in India as of 2004 (UNAIDS, 2004). Between 2000-15, the UN estimates there will be 12.3 million AIDS deaths and 49.5 million deaths during 2015-50 (Population, 2002). A report by the National Intelligence Council predicts 20 million to 25 million AIDS cases in India by 2010, more than any other country in the world (National, 2002).

Of special concern to business is the possible impact of this crisis on India's skilled IT workforce (Sengupta \& Sinha, 2005). HIV positive men in India have a 3:1 ratio to women, but there are fears this will change and resemble South Africa in the near future (UNAIDS, 2004). However, even with a funding source from Bill Gates, assisting in the fight against HIV/AIDS, the fears remain due to lack of education, lack of a coordinated effort between government and private sector, lack of consistent involvement by business leaders (UNAIDS, 2004; Sengupta \& Sinha, 2005). The International Labor Organization (ILO) predicts that AIDS will have killed 6 million workers in India by 2010 (Arnst \& Einhorn, 2004).

HIV/AIDS is also prevalent in China. Currently it is estimated that $1 \%$ of the population is HIV positive, however, in a country the size of China, $1 \%$ represents 1 million people (UNAIDS, 2004). There is currently a 30\% annual increase in the number of HIV cases in China (UNAIDS, 2004). Such an alarming increase in HIV cases is of concern to the government and business. Every province in China has been affected by HIV/AIDS and it is thought that by 2010, there will be 10 million cases of HIV/AIDS if the disease is left unchecked (UNAIDS, 2004). Another concerning statistic is that in the 1990s the male to female ratio of HIV/AIDS infection was 5:1, it is now closer to 2:1 (HIV, 2005). The ILO predicts that 1.8 million workers in China will die from AIDS by 2010 (Arnst \& Einhorn, 2004).

There is an estimate 8.2 million people living with HIV/AIDS in Asia (including those discussed in China) and the number of women living with HIV/AIDS has increased 56\% since 2002 (UNAIDS, 2004). Of concern is the impact HIV/AIDS will have on developing economies throughout the region. As noted in Africa, agricultural output will be affected, as families have to reorganize their activities to account for decreased labor availability. Some of China's regions are primarily rural and agricultural. These areas, which are fighting poverty and limited healthcare access already, will be hard hit by the epidemic (UNAIDS, 2004). Elizabeth Blunt (2003) noted that fourteen percent of the people BBC surveyed in China did not know what AIDS was; they could not identify it as a disease or something you might die from (Blunt, 2003). The people contacted for the survey were located in five of the largest cities in China. Education and coordinated efforts are needed.

Russia is another area on the verge of an AIDS/HIV crisis. Again, current estimates have HIV/AIDS infection at approximately $1 \%$ of the population, or 860,000 people (UNAIDS, 2004). All regions of Russia have been touched by HIV/AIDS, and the concern is similar to that voiced for Africa, India and China - the largest population that is HIV positive is 15-49 years old and that directly impacts productivity and economic growth of the regions (UNAIDS, 2004). Similarly to the discussion regarding the other countries, government and business in Russia have been slow to develop coordinated policies, therefore global concern is that the epidemic will spread quickly before significant action is taken.

It is fairly obvious that HIV/AIDS has raised the risks and the costs of doing business in South Africa, thereby decreasing the competitive advantage of businesses in those areas. But of greater concern is "the threat HIV/AIDS poses to companies in other developing countries like China and India has so far been ignored" (Rosen, et al., 2003, p. 87) 


\section{WHY SHOULD BUSINESS GET INVOLVED IN THIS FIGHT?}

The disease is a bottom line issue for business (Pela, 2004a). A prime example of how much a bottom line issue HIV/AIDS is can be found by looking at MTV. MTV has become an international champion of the fight against HIV/AIDS. Why? There are many reasons. From a business perspective one has to recognize that "more than half of the new HIV infections hit people under 25. Left unchecked, AIDS will kill off MTV's audience" (Gunther, 2004). Young people - 15-24 yr olds - account for nearly half of all new HIV infections worldwide (UNAIDS, 2004).

"The only cost-effective way to respond is to fight the epidemic" (Rosen, et al, 2003). If multinationals don't embrace aggressive anti-AIDS tactics, both their employees and their customers in emerging markets will inevitably fall victim to the epidemic (Arnst \& Einhorn, 2004). AIDS is a major business risk in terms of absenteeism, loss of skills and knowledge transfer, and decreased productivity. The estimated cumulative worker death toll from AIDS is 28 million for 2005, 48.2 million by 2010, and 74.2 million by 2015 (Arnst \& Einhorn, 2004). Many businesses are fighting this challenge by hiring more workers than needed and training them for more than one position in hopes of impacting falling productivity levels (Rosen, et al., 2003, UNAIDS, 2004). The International Labor Organization predicts that the labor force in 38 countries (all but 4 in Africa) will be 5\% - 35\% smaller by 2020 because of AIDS (UNAIDS, 2004).

The rising cost of labor, due to increased healthcare costs, turnover and retraining, are not the only concerns for business. AIDS is also reducing the demand for good and services in developing markets as the virus is often striking the breadwinner of the family (Rosen, et al., 2003). This epidemic is impacting the financial viability of many families from the impact on the breadwinner, to the children pulled out of school to help work or care for a sick parent, thus reducing the skill base of the future labor pool.

There are several direct and indirect costs of AIDS to an employer. As mentioned previously Aventin \& Huard (2000) identified several costs to 3 African corporations. Similar results were noted in another study (Rosen, et al., 2003, p. 84):

\begin{tabular}{|ll|}
\hline \multicolumn{1}{|c|}{ Direct Costs } & \multicolumn{1}{c|}{ Indirect Costs } \\
\hline Medical Care & Reduced on the job productivity \\
Benefits payments & Reduced productivity due to absenteeism \\
Recruitment/training of replacements & Supervisor's time re: productivity issues \\
& Vacancy Rate until replacement hired \\
& Reduced productivity from new hire learning \\
Insurance premiums & Senior management time \\
Accidents due to ill workers & Production disruptions \\
Accidents due to inexperienced workers & Depressed morale \\
Costs of litigation over benefits, etc. & Loss of experienced workers \\
& Deterioration of labor relations \\
\hline
\end{tabular}

Some of the above-mentioned expenses are from an individual employee becoming ill, while others are organizational expenses due to increased incidence of the illness.

While HIV/AIDS impacts areas and companies differently, depending upon the prevalence (and accessibility) of high-risk behavior, prevention and treatment will pay off in financial terms for most companies via productive workforces (Rosen, et al., 2004; UNAIDS, 2004). Additionally, investing in socially responsible actions of education, prevention and treatment programs has the added benefit of increasing corporate status and generating goodwill. 


\section{WHAT'S NEXT?}

MNCs have several resources to access for additional information on programs and partnerships. The CocaCola Foundation is very active in Africa and they have developed partnerships with bottling companies and vendors throughout the continent (Coca-Cola, 2004). Their programs are often mentioned as resources or examples to businesses that want to have an impact on the disease and its toll on business (Arnst \& Einhorn, 2004; UNAIDS, 2004; Bloom \& Mahal, 2001). The United Nations AIDS organization is very active throughout the world in lending support and materials in the fight against HIV/AIDS (UNAIDS, 2004).

Bloom and Mahal (2001) examined the literature on AIDS in the workplace. This literature review included an examination of the current response to the epidemic by business. Several businesses have noted increased absenteeism, reduced profits, and significant increases in medical care costs (Bloom \& Mahal, 2001). To combat these problems, cooperative programs between MNCs, NGOs and government are beginning to be established. However, the private sector has seen "governments and NGOs as ineffective bureaucracies " while the public sector has viewed business as "selfish and hypocritical" (Gupta \& Taliento, 2003, Bloom \& Mahal, 2001).

Collaboration is a two-party event and without the proper tools and skills, it can be difficult to attain. Success in dealing with the HIV/AIDS epidemic will be beneficial to both the public sector as well as business. There are prior examples available that demonstrate a successful collaboration, but these resources are limited in number (Bloom \& Mahal, 2001). One tool not mentioned in any of these articles or examples is that of business diplomacy management.

Business diplomacy management, the ability to manage complex political-economic environments, is a tool useful in negotiating the intricate realm of global business. Some of the skills involved in business diplomacy management include the following: influence economic and social actors, work with rule-making international bodies whose decisions impact international business, minimize political risks, shape policies, interact effectively with various cultures, balance multiple interests and loyalties, safeguard corporate image and reputation through international media outlets (Saner, Yiu \& Sondergaard, 2000). Recognizing that the global business environment is complex and that stakeholders include new players, such as NGOs, is one of the first steps to success in a global enterprise. Leveraging your resources increases competitive advantage, and if your resources include managers with business diplomacy skills, the organization's effectiveness in the marketplace increases.

Business diplomacy management is especially useful in helping "global companies forecast, plan and manage international issues; cope with multiple crises; influence and work with intergovernmental organizations; and know how to operate appropriately within diverse cultural and societal environments" (Saner, Yiu, \& Sondergaard, 2000 , p. 83). These skills could go a long way in working with government agencies and NGOs as discussed in Bloom and Mahal (2001). Having global managers trained in business diplomacy increases the productivity and efficiency of meetings as "business diplomacy managers offer a better synergy of business interests, corporate values, and the management interface with external constituencies" (Saner, Yiu, \& Sondergaard, 2000, p. 90). Managers with this skill set can make a MNC more proactive and less prone to crisis especially in regards to providing coordinated services to the workforce.

Business diplomacy management appears to be a potential tool needed to enhance effective communication between NGOs and business in regards to HIV/AIDS interventions (Saner, Yiu, and Sondergaard, 2000). This skill could allow for greater coordination of efforts between the MNC and NGO to assist employees and family members in getting the education and treatment needed.

Another consideration is cultural competence. Expatriates have been trained to various degrees on the host country culture. But, as noted in this paper, a new issue is attacking cultures across the globe - HIV/AIDS. Managers, expatriates, and various home office departments must develop cultural intelligence to increase their understanding of the host country situation. Having cultural intelligence means that the employee knows what culture is, how cultures vary and how culture affects behavior (Thomas, 2005). 
Redesigning employee benefit packages is a consideration. Coca-Cola and GM are two MNCs that now included HIV/AIDS services, education and prevention programs while working to avoid discrimination against infected employees (Arnst \& Einhorn, 2004; Coca-Cola, 2004). Business has another role to play - lobbying governments to respond to the epidemic, educate workers about AIDS, and provide treatment to employees (Gunther, 2004). Of over 7,000 business executives from 103 countries, " $21 \%$ stated they expected HIV/AIDS to have a serious impact on their business and their community...but only $6 \%$ of the firms said they had a written policy covering topics related to HIV/AIDS prevention, treatment, and discrimination in recruitment, promotion or pay" (Gunther, 2004).

\section{SUMMARY}

"HIV/AIDS is a threat to sustainable global and social economic development" according to Juan Somavia of the ILO (Arnst \& Einhorn, 2004, p. 78). AIDS related illnesses and deaths of workers affect employers by increasing their costs and reducing revenues. They have to spend more in areas such as health care, funeral, training and recruitment of replacement employees. Revenues may be decreased because of absenteeism due to illness or attendance at funerals as well as time spent on training. Labor turnover can lead to a less experienced and therefore less productive work force with increased accidents. HIV/AIDS also impacts the growth of economies and decreases the demand for goods and services in developing nations. There is bound to be a reduction in profits, and competitive advantage, if companies do not take early measures to prevent the impact of HIV/AIDS on their workforce.

Human resources focuses on recruiting, selecting, developing and maintaining an effective and efficient workforce. Staffing, and all of the issues that impact it, are of a major concern to global human resource departments. In the past, the focus for IHRM has been on compensation \& benefits, retirement plans, cultural competence and the use of expatriates, now IHRM must examine a new culture - the culture of HIV/AIDS in the workforce (Janush, 2003).

Companies in India, China and other parts of Asia are not reacting quickly to the potential problems of the HIV/AIDS epidemic in those areas. Disseminating information to those slow to move business leaders in a manner that explains the risks in a cost benefit analysis is needed. Additional education in effective communication techniques with NGOs appears to be needed. A reminder of the benefits of socially responsible actions and "reputational capital" could also prove beneficial in getting cooperation and action (Saner, Yiu, \& Sondergaard, 2000).

Finally, introducing and training in the concept of business diplomacy could prove to be an effective tool in increasing meaningful communication between various stakeholders.

"Any multinational that can't see how it is directly affected by the global disease epidemic is dangerously myopic" (Gupta \& Taliento, 2003).

\section{REFERENCE}

1. Arnst, C. \& Einhorn, B. (2004, August 9). Why business should make AIDS its business. Business Week, 3895, p. 83.

2. Aventin, L. \& Huard, P. (2000). The costs of AIDS to three manufacturing firms in Cote d'Ivoire. Journal of African Economies, 9(2), 161-188.

3. Bloom, D. E. \& Mahal, A. (2001). HIV/AIDS and the private sector - a literature review. Retrieved July 23, 2005 from the World Wide Web: http://www.iaen.org/files.cgi/7050 bloom_private sector.pdf?PHPSESSID=c7e80f3f061f089b8c5efdd28f30 6flc.

4. Blunt, E. (2003, November 12). AIDS in China: ignorance about the disease. Retrieved July 23, 2005 from the World Wide Web: http://www.bbc.co.uk/worldservice/learningenglish/newsenglish/witn/031112_witn.shtml.

5. Coca-Cola Foundation. (2004). Our HIV/AIDS initiatives in Africa. Retrieved July 23, 2005 from the World Wide Web: http://www.aidsreport.coca-cola.com. 
6. Dixon, S., McDonald, S., \& Roberts, J. (2002). The impact of HIV and AIDS on Africa's economic development. British Medical Journal, 324(7331), 232-234.

7. Govindarajan, V. \& Gupta, A. K. (2001). The quest for global dominance: transforming global presence into global competitive advantage. San Francisco: Jossey-Bass.

8. $\quad$ Gunther, M. (2004, September 6). A crisis business can't ignore. Fortune, 150(5), 72-73.

9. Gupta, R. K. \& Taliento, L. (2003). How businesses can combat global disease. The McKinsey Quarterly, p. 100 .

10. HIV rates rise in Chinese women (July 11, 2005). Retrieved July 18, 2005 from the World Wide Web: http://news.bbc.co.uk/go/pr/fr/-/1/hi/world/asia-pacific/4671569.stm.

11. Janush, E. (2003). Issues in global human resources. Risk Management Magazine, 50(7), 42.

12. Kwaramba, P. (1997). The socio-economic impact of HIV/AIDS on communal agricultural production systems in Zimbabwe. UN Secretariat, 5(3).

13. National Intelligence Council. (2002). The next wave of HIV/AIDS: Nigeria, Ethiopia, Russia, India, and China. Retrieved July 23, 2005 from the World Wide Web: http://www.avert.org/aidsindia.htm.

14. Negin, J. (2005). Assessing the impact of HIV/AIDS on economic growth and rural agriculture in Africa. Journal of International Affairs, 58(2), 267-281.

15. Pela, M. (2004, April 6). AIDS takes toll on S. African businesses. Medical Post, 40(14), 67.

16. (2004, April 20). South Africa's government workforce seriously affected by AIDS. Medical Post, $\overline{40(16), 64 .}$

17. Population Division of the Department of Economic and Social Affairs of the United Nations Secretariat. (2003). World population prospects: the 2002 revision. Retrieved July 23, 2005 from the World Wide Web: http://www.avert.org/aidsindia.htm.

18. Rosen, S., Simon, J., Vincent, J. R., MacLeod, W., Fox, M., \& Thea, D. M. (2003). AIDS is your business. Harvard Business Review, 81(2), 80-87.

19. Saner, R., Yiu, L., \& Sondergaard, M. (2000). Business diplomacy management: a core competency for global companies. The Academy of Management Executive, 14(1), 80-92.

20. Sengupta, J. \& Sinha, J. (2005, January 21). Battling AIDS in India. The McKinsey Quarterly. Retrieved July 23, 2005 from the World Wide Web: http://www.mckinseyquarterly.com/article page.aspx?ar=1430\&L2=19\&L3=69.

21. Singh, J. A. (2004, November 27). Why AIDS in South Africa threatens stability and economic growth in other parts of Africa. The Lancet, 364(9449), 1919-1920.

22. Taylor, K. \& DeYoung, P. (2003-2004). Business and HIV/AIDS: who me? World Economic Forum's Global Health Initiative. Retrieved July 23, 2005 from the World Wide Web: http://www.unaids.org/html/pub/topics/partnership-menus/wef-ghi_businesshiv-aids_(full)_04_en_pdf.pdf.

23. Thomas, D. C. (2005). Cultural intelligence. Consulting to Management, 16(1), 5-9.

24. UNAIDS (2004). United Nations AIDS Epidemic Update retrieved July 23, 2005 from the World Wide Web: http://www.unaids.org/wad2004/report_pdf.html.

25. UNPFA State of World Population. (2004). The Cairo consensus at ten: population, reproductive health and the global effort to end poverty. Retrieved July 23, 2005 from the World Wide Web:

http://www.unfpa.org/swp/2004/pdf/en_swp04.pdf. 